\title{
A Dark Cloud, a Passing Cloud and Finally a Silver Lining: A Story about Hope, Learning and Reintegration into Society Lynne Elliott
}

I was six weeks pregnant upon entering a five-year sentence.

This was my drive to not become a statistic... hope you like it... Lynne

$\mathrm{T}$ his is one thing I could count on as I went through the day to day affairs of my life: A DARK CLOUD! You see, I was one of those teenagers who could get by in high school and not have to worry about the future because once I skated through high school, I knew all there was to know and didn't need any further learning to get through life!

Not really what you would call street smart, but, common sense was on my side and I could say I had a high school diploma. What else could a person need to start being an adult? If I get on the wrong track, my parents will help me pick-up the pieces and move on, and I really don't seek to be a rocket scientist or anything major like that. Besides, if I changed my mind later, I had decent grades in high school, so I wasn't totally against college, just not ready to commit to that yet.

That was my way of looking at things. Does anyone ever really know how their life can change in the blink of an eye? I promise you, they don't!

But, what is truly amazing is that some of the greatest answers come in the darkest and most unusual places, which is why I feel that through even the worst experience of my life, I was blessed. A PASSING CLOUD. As I go through my day to day affairs now, in this place, I know I am here, but I no longer hold my head down and wonder, "what if". Now, I am taking action!

I am a female prisoner in a Federal Prison Camp. But, the great thing is that I know this is only A PASSING CLOUD! I know because I am growing. I am growing because I am learning. I am learning because I am adding layers to my foundation of life, one step at a time, with education.

What a word! EDUCATION. It provides all the tools to success, career, smart choices, decisions, speaking, family values, wealth, knowledge, sympathy, empathy, advancement, and above all, direction and self worth! LEARNING! The answer was so simple all along that I don't quite understand why so many people never get it! Simply put, when you get it, it gives you freedom and growth. Growth like you've never known, answers 
you've never had, and choices that would be permanently untouchable and unreachable without it! How did I miss it? How do so many people miss it?

We, as a society, are so quick to make excuses for the reasons we DON'T need it, that, just like myself, we overlook the many positive reasons we should explore and emphasize it! I shudder to think of the many lost souls that I am surrounded by who have never experienced learning and the freedom it gives you when you set forth on a path of education.

As I sit in my classes at the prison camp, I am so engrossed in what I am learning that I feel as though I have been free forever even though I am, as society says, 'locked up'. A SILVER LINING! I will not be a statistic. And I will not allow anyone to treat me as one. I have something now that I have earned that most people search for all of their life. What I have is SELF WORTH and DIGNITY! I have ammunition! I have all of the tools to be a successful, kind, contributing member of society.

I came to prison five years ago, pregnant, confused, hurt and lonely. And above all, with a lot of shame and guilt, with absolutely no direction. With the ammunition I have now, I will be leaving here a positive, humble, driven and confident woman. I have a new love called EDUCATION. My partner in life. I will share it with everyone because it is too special to be selfish with.

This is my SILVER LINING! Knowledge, hope, wisdom, self worth, direction and confidence. The sky is the limit! This silver lining will assure that my DARK CLOUD will always be a PASSING CLOUD because there are only sunny days ahead in my future.

\section{Justice Served?}

Making sense of it now would never happen.

I looked around and knew that I had stepped into the lions den.

Women with stories of abuse, pain and sorrow.

Most growing up wondering if they would eat tomorrow.

I entered this place unsure and with child.

I quickly realized this process would be anything but mild.

I had heard the phrase 'going thru the motions'.

Clearly it felt much like waves in the ocean.

My charge is conspiracy, a charge they don't have to prove. The only comfort I get is when I feel the baby move. 
The sentence was harsh and I am so confused.

Twelve years for that, the prosecutor wasn't even amused.

The girl next to me murdered her child.

But, she's only here for a very short while.

Justice served? I think not!

But, that's what the judge says I've got!

My sentence was cut, it's five years now.

My son has grown, but, I wasn't there to see how.

Instead I was here, but not in vain.

I studied hard so not to go insane.

I earned two degrees to help me when I get out of this place.

I made it through the nightmare, but only by grace.

The statistics and society say a felon will never be much.

What most don't realize though is that education is my crutch.

My son is with me now, after all these years.

His resilience and smile always bring me to tears.

Life is good now and I have started to smile.

I must admit though, it took quite awhile.

Strength, it seems, comes from very deep.

The rewards I get now, are all for me to keep.

Justice served? That's pretty lame.

But, whatever they threw at me, I no doubt overcame!

Things in my life, at present time, I will not allow.

I've come too far and not slowing down now.

The time was hard, prayers and study got me through my day.

Because I'm not going back, no how or no way! 


\begin{abstract}
ABOUT THE AUTHOR
Lynne Elliott is a former federal prisoner in the United States who entered prison when she was six weeks pregnant. She did not see her child, a beautiful boy, again until he was five years old. While incarcerated, she earned enough college credits for two associate degrees and became a certified paralegal. Upon release, Lynne worked two full-time jobs and held a paper route. She now works for a chemical corporation and has full custody of her little boy who is now almost twelve years old. Lynne's motto is that "if you are given a second chance, you better give it all you've got".
\end{abstract}

